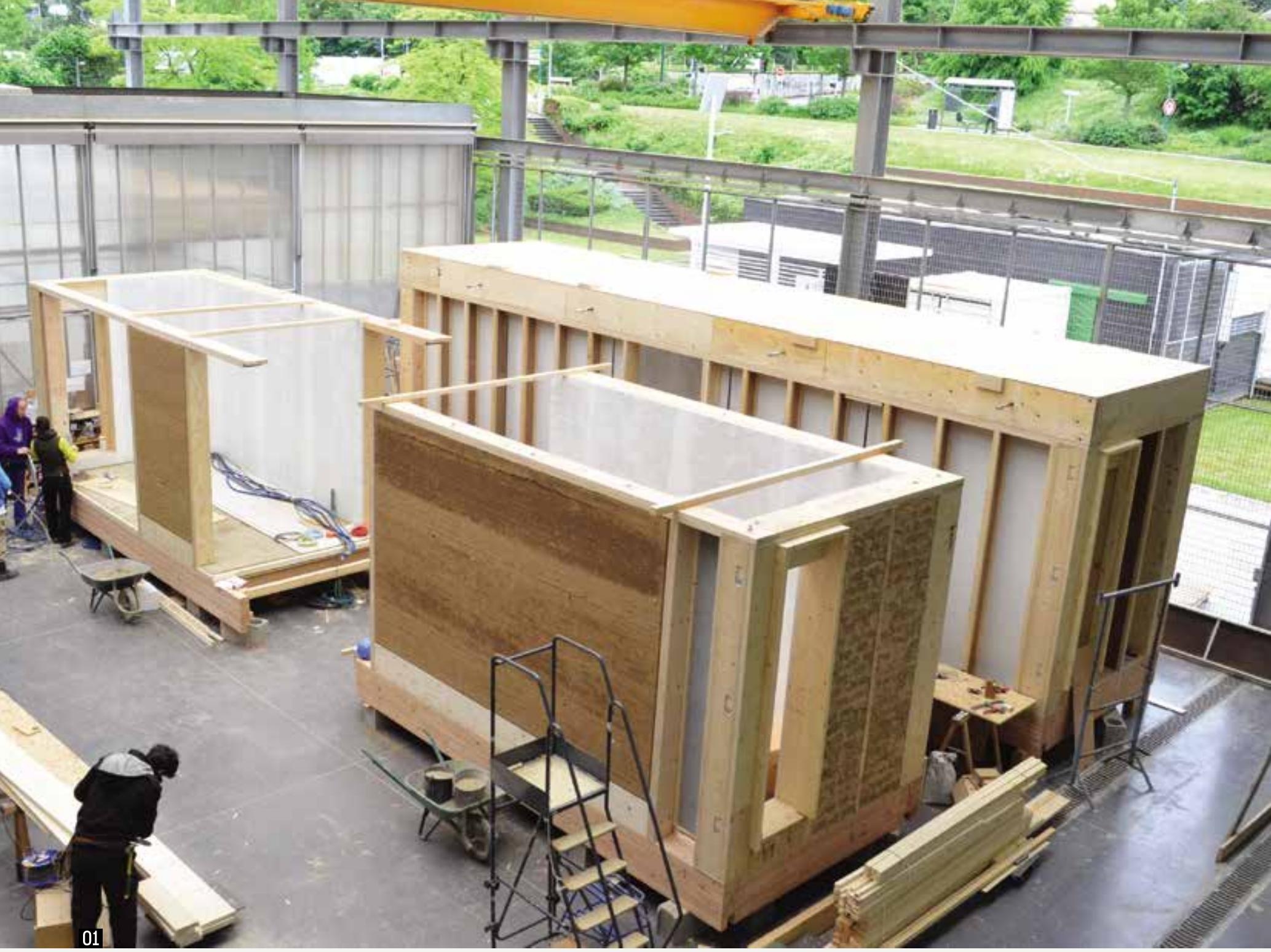

\title{
A VÁLYOGÉPÍTÉS JELENE ÉS VÁRHATÓ JÖVŐBENI TENDENCIÁl
}

SZERZŐ |

Bihari Ádám,

Medgyasszay Péter

_ Az építőipar számos új kihívás előtt áll a 2020-as években.

A természeti környezet korlátossága, a klíma változása mára már nyilvánvaló. Az élet szinte minden területén megjelentek az egyre komplexebb, sokszor mesterséges intelligenciával támogatott eljárások. A globalizáció, urbanizáció erősödik, az egyéni fogyasztás mértéke nő.
_ A vályogépítés több ezer év alatt kialakult tradicionális formáiban nem képes ezekre a kihívásokra válaszokat adni. A vályogtechnológiák mai for- 01 máiban azonban vannak olyan előképek, amelyek fejlesztésével lehetőség van egyes fenti kérdések megválaszolására.

_ A cikk arra keresi a választ, hogy az EU területén belül a vályogépítésnek milyen tendenciái várhatók az elkövetkező években. A jelenlegi gyakorlat elemzésekor a magyarországi példák mellett az uniós szintű rálátás érdekében a francia és német példákat tekintjük át.

\section{A VÁLYOGÉPÍTÉS ELŐNYEINEK ÉS HÁTRÁNYAINAK BEMUTATÁSA}

— A vályogépítéssel, a vályog anyagtulajdonságaival kapcsolatban a nemzetközi szakirodalom és gyakorlat a hazai köz- és szakmai vélekedéssel esetenként ellentétes vagy jóval árnyaltabb állításokat fogalmaz meg. 


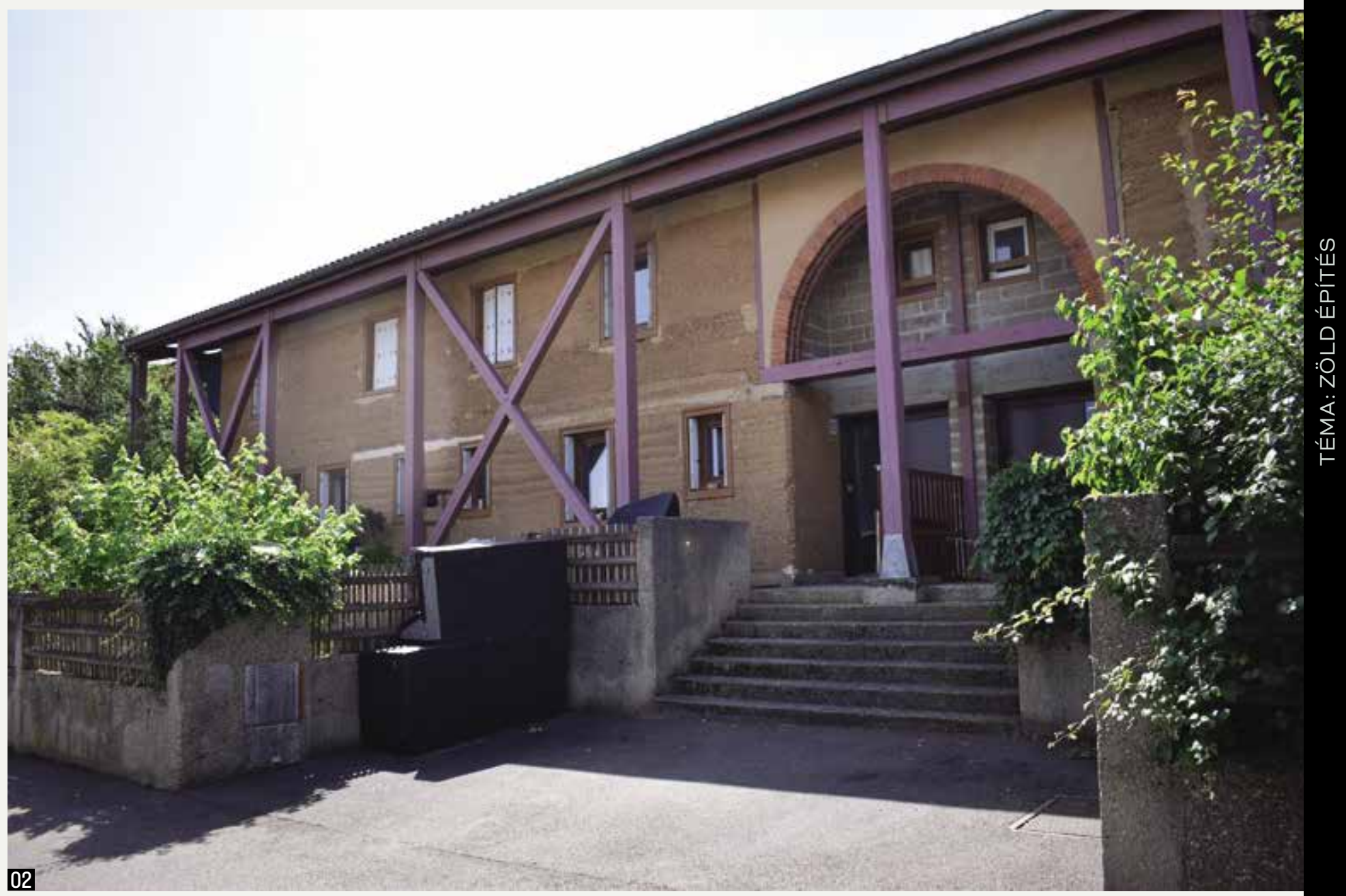

\section{A VÁLYOG ELŐNYÖS TULAJDONSÁGAI}

_A vályog kiemelkedő szorpciós képességeiben az összefoglaló jellegű nemzetközi [2],[8] és hazai szakirodalmak [4],[9] és a rövidebb, specifikus tudományos cikkek is egyetértenek.

_ Ugyancsak egyetért a szakirodalom a vályog átlagos anyagoknál magasabb hőtároló képessége tekintetében. Mindezeknek köszönhetően elmondható, hogy a vályog az emberi hőérzet és klímakomfort szempontjából kifejezetten kedvező hatású. [5]

_Fenntarthatósági szempontból kiemelkedő a teljesítménye. Mivel a vályog épületszerkezetek gyártásuk és építésük során nem esnek át magas hőfokú égetésen és mesterséges adalékok hozzáadásán, vagyis 100\%-ban természetes anyagokból épülnek föl, teljes egészükben újra felhasználhatóak vagy közvetlenül visszaforgathatók a természetbe. A beépített primer energiatartalmuk minimális. [8]

_ Faanyagokkal közösen épített szerkezetek esetén megfigyelhető, hogy a vályog a fát hatékonyan konzerválja, a biológiai kártevőkkel szemben ellenállóbbá teszi. Tüzvédelmi szempontból elmondható, hogy gyakorlatilag nem éghető. Nagy tömege révén kedvező akusztikai tulajdonságokkal rendelkezik.

_ Mindezek mellett könnyen formálható, emberi erővel is megmunkálható anyag, mely világszerte számos helyen nagy mennyiségben hozzáférhető, felhasználásának gyakorlatilag nincsenek mennyiségi korlátai. [2]

\section{A VÁLYOG HÁTRÁNYOS TULAJDONSÁGAI}

_ Figyelembe kell venni, hogy a vályogfalaknak robusztusságuk ellenére nincs kiemelkedő nyomószilárdsági teljesítményük, és elhanyagolható a húzó- és hajlítószilárdságuk. [3], [7] Ennek következménye, hogy szeizmikusan aktivitásra - kiegészítő merevítő rendszer nélkül - rendkívül érzékenyek.

_Egy elterjedt tévhit a vályoggal kapcsolatban, hogy jó hőszigetelő képességű anyag. Ennek éppen az ellenkezője igaz. Mivel nagy térfogatsúlyú, így jó hővezető, következésképpen rossz hőszigetelő.

—A konvencionális építőanyagokhoz (égetett kerámiák, beton, acél stb.) képest a vályogfal nedvességérzékenysége magas. A jelentős nedvességfelvétel szilárdságcsökkenést eredményez. [I]

_ A vályog is elsősorban a saját építési rendszerében kompatibilis más anyagokkal, melyek a természetes alapú anyagok: fa, szalma, kender, mész. Vakolattartási problémák merülhetnek fel különösen cementes vakolatok vályogfalra építése esetében, és vályogvakolat sem építhető közvetlenül betonfalra. 

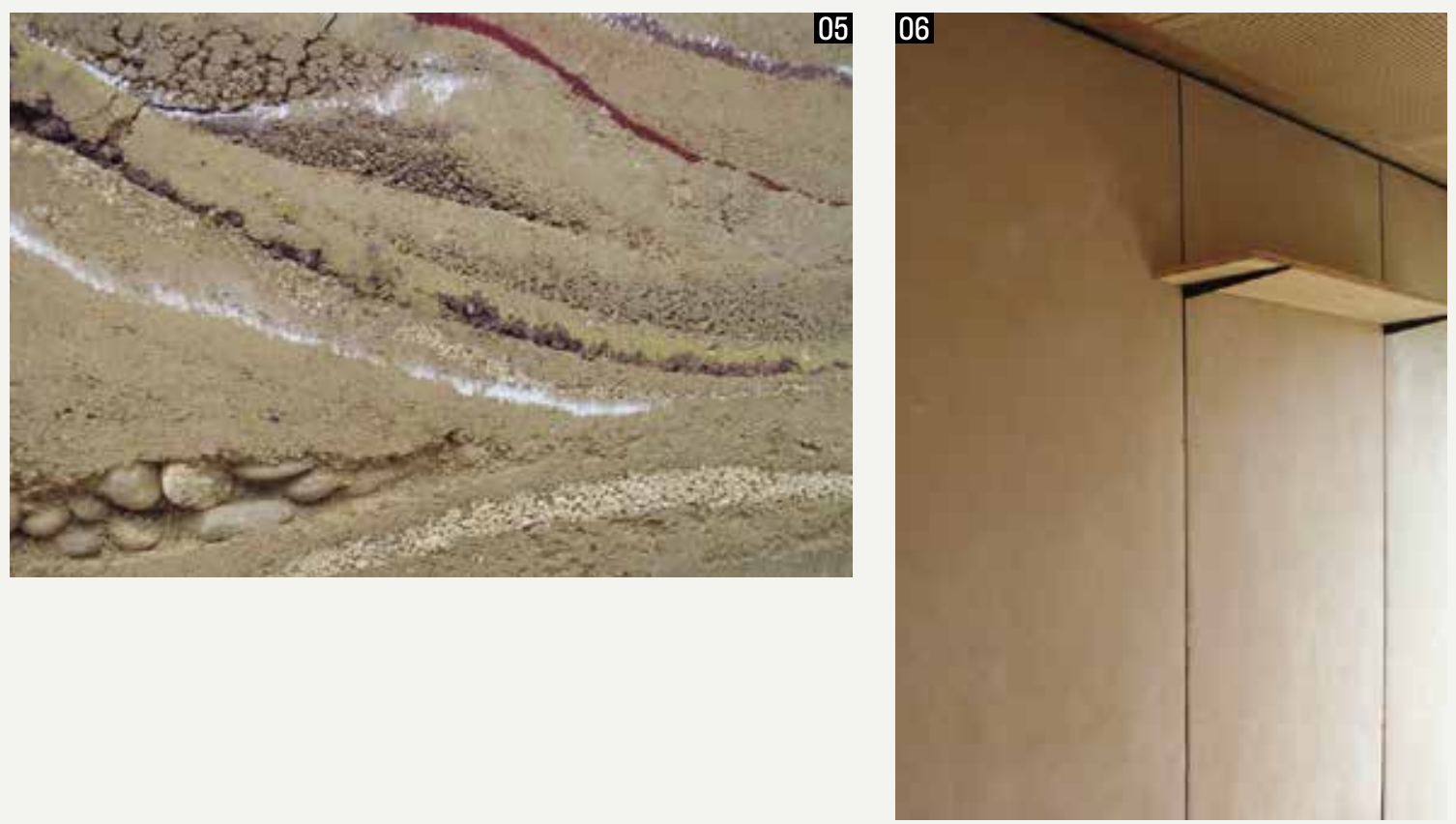

_ Mivel természetes anyag, problémát jelenthet a biológiai kártevőkkel (rovarok, gombák) szembeni érzékenység és az inhomogenitás. A különböző vályogtalajok sokféle agyagásványból és görgetegfrakciókból épülnek össze. Ezek egy része nedvességfelvétel közben jelentős duzzadásra, száradás közben pedig zsugorodásra hajlamos. __ Szintén hátrányos tulajdonság, hogy az alapanyag könnyű hozzáférhetőségével szemben rendkívül idő-és élőmunka-igényes a tradicionális vályogszerkezetek kivitelezése.

\section{JELENLEGI GYAKORLAT BEMUTATÁSA}

_ A vályog építőanyag használata több helyen divatba jött környezettudatos építők körében. Az EU több országában alakultak ki kutatásával foglalkozó központok. Megindult új termékek fejlesztése, és trenddé vált, hogy a vályog mint exkluzív belsőépítészeti elem jelenik meg az épületekben látszó réteges vert falazatként vagy dekorvakolatként.

_ Magyarországon a nagyszámú vályogépítészeti örökség mellett a kortárs vályogtermékek is megjelentek, amelyek kitöltő szerkezetként, felületképzésként széles körben használhatóak. [6] Az iparosított technológiához közelítő vályogtermékekre, -technológiákra a táblázatban bemutatott példákat találtuk.

\section{JÖVŐBEN VÁRHATÓ TENDENCIÁK}

_A vályogépítés jövőképét a jelenleg érzékelhető trendekből és szakirodalmi forrásokból próbáljuk meghatározni azzal a feltételezéssel élve, hogy a globális gazdaság bővülő, fenntartható pályán tud fejlődni. A hazai és a nemzetközi szakirodalom, [Io] (I-5. pont) és saját meglátások (A-H pontok) alapján a következőket azonosítottuk a vályogépítés és -építészeti tervezés jövőjét érintő kihívásokként:

I. A virtuális valóság egyre nagyobb szerepet kap a tervezések során.

2. A teljes életciklust kísérő komplex épületmodellezés, adatkezelés (BIM) egyre általánosabbá válik.

3. A mesterséges intelligencia segíti, formálja a jövő épületeinek formavilágát.

4. Az építés robotizálódik, a 3D nyomtatás nagyobb szerepet kap az építések során.

5. A fenntarthatóság hármas szempontrendszerének (környezeti, társadalmi, gazdasági fenntarthatóság) általánossá válása.

04 A) Európai szinten a nagyvárosok koncentrálódása helyett vélhetően jellemzőbb lesz a kisvárosi (40 000500 ooo fő) környezet terjedése, a falusi-községi településszövet arányának visszaszorulása.

B) Az épület egyre inkább termékké válik. Az egyediségre való igény megmarad, de konfekciómegoldásokra lesz a legnagyobb igény.

C) Építési rendszerek fejlődnek ki, a közöttük való átjárhatóság egyre korlátosabbá válik.

D) Az építési idő lényegesen lerövidül.

E) A helyszíni élőmunka visszaszorul.

F) Az egészséges belső terekre egyre nagyobb lesz az igény.

G) Az épületek bekerülési költsége reálértéken növekszik.

H) A klímaváltozás hatásaihoz való alkalmazkodás során az épületekkel szemben támasztott követelmények módosulnak. 


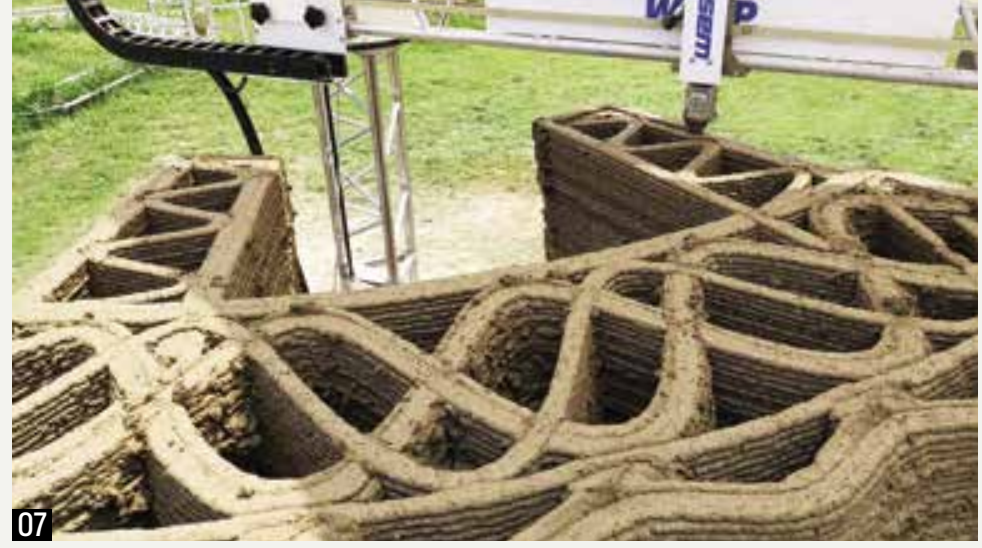

03 Könnyűvályog építőlemez hajlítópróba, fotó: Bihari Ádám

04 Szerelt vályog építőlemez falon vályogvakolat több rétegben, fotó: Bihari Ádám

05 Dekor döngölt vályog falfelület, fotó: Bihari Ádám

06 Készülő vályog falfütés panel, fotó: Bihari Ádám

07 3D nyomtatásos vályogház, forrás: 3D Wasp

A cikk a 2018-2.1.15-TÉT-PT-2018-00005 számú projekt keretében a Nemzeti Kutatási, Fejlesztési és Innovációs Alapból biztosított támogatással, a „Kétoldalú tudományos és technológiai (TéT) együttműködés támogatása a magyar-portugál relációban” pályázati program finanszírozásában valósult meg.

\begin{tabular}{|c|c|c|}
\hline Ország & Technológia & Funkció \\
\hline \multirow[t]{5}{*}{ Maǵyarország } & extrudált tömör vályogtégla & kitöltő fal \\
\hline & extrudált üreges vályogtégla & kitöltő fal, válaszfal \\
\hline & géppel préselt földtégla & kitöltő fal/teherhordó fal \\
\hline & zsákos vályog & belső vakolat \\
\hline & zsákos vályog & falazóhabarcs \\
\hline \multirow[t]{4}{*}{ Németország } & vert vályog & esztétika/hőtárolás \\
\hline & préselt könnyűvályog & belső oldali hőszigetelés \\
\hline & farostba préselt vályog & nehéz építőlemez \\
\hline & nádszövetre préselt vályog & építőlemez \\
\hline \multirow[t]{3}{*}{ Franciaország } & vályogpanel (építőlemez) & szerelt falak \\
\hline & vályogpadozat & padlóburkolat \\
\hline & öntött látszó vályogfalazat & külső, belső falazat \\
\hline
\end{tabular}

Vályog építési termékek Magyarországon, kiegészítve a Magyarországon nem elérhető német és francia termékekkel
IRODALOM / REFERENCES

[1] Champiré, $F$ et al: „Impact of relative humidity on the mechanical behavior of compacted earth as a building material", Construction and Building Materials, Vol 110 (2016), pp 70-78.

[2] Houben $\mathrm{H}$, - Guillaud, $\mathrm{H}$ : Earth construction, Intermediate Technology Publication, London 1989.

[3] Maniatidis, V - Walker, P: A Review of Rammed Earth Construction for DTi Partners in Innovation Project 'Developing Rammed Earth for UK Housing' (2003).

[4] Medgyánszky, Miklós: Vályogházak - Épités, korszerüsités, átalakítás, Terc Kiadó, 2005.

[5] Medgyasszay, P - Novák, Á: Föld- és szalmaépitészet, Terc Kiadó, 2006.

[6] Medvey, B - Bihari, A - Medgyasszay, P: „Természetes építőanyagok szabályozása, különös tekintettel a vályog építési anyagokra és technológiákra", Metszet, Vol 9, № 6 (2018), pp 84-91.

[7] Morel JC, et al (2008): „Compression behaviour of nonindustrial materials in civil engineering by three scale experiments: the case of rammed earth", Materials and Structures.

[8] Minke, Gernot: Lehmbau Handbuch, Ökobuch Verlag, 1999.

[9] Szűcs, Miklós: Föld- és vályogfalú házak épitése és felújitása, Épitésügyi Tájékoztatási Központ, 2002.

[10] Kovács, Ádám Tamás: „Az építészeti tervezés jövője Magyarországon az elkövetkező 20 évben”, in MTA Jövőkutatási Tudományos Albizottság (ed): A múltból átívelő jövő, vIII Magyar (Jubileumi) Jövőkutatási Konferencia, Platina 2018, pp 329-339.

\section{KONKLÚZIÓ}

_ Trendként már napjainkban is megfigyelhető a meglévő, általános építési technológiákkal kompa- 05 tibilis vályogtermékek alkalmazásnak terjedése. _ A jelenleg alkalmazott vályogépítési technológiák azonban jellemzően még nem elégítik ki a jövőben várható igényeket.

\section{_ Szükséges:}

I. rendszerszintű megoldások szabványosítása épületszerkezeti és teljes épület szinten;

2. az intelligens tervezéssel kompatibilis elemek létrehozása;

3. előregyártott, gyors építkezést lehetővé tevő, robotizálható építési technológiák kifejlesztése; 4. a vályog alkalmazásával elérhető egészségügyi, környezeti, gazdasági előnyök számszerűsítése, publikálása, népszerűsítése.

A jövőben az építés egyes szegmenseiben (belső oldali felületképzés, tömegképzés) várható, hogy a vályogépítés előnyeinek köszönhetően kis mértékben megnő a kor igényeit kielégíteni képes vályogtermékek piaci részesedése. 


\section{ABSTRACTS}

\section{WESSELÉNYI-GARAY, Andor: AFTER POST ORGANIC ARCHITECTURE \\ Citation: Metszet, Vol 11, No 4 (2020), pp 11-17, DOI: 10.33268/Met.2020.4.1 \\ FAMILY HOME, BUDAKESZI, HUNGARY | Architect: Gábor and Orsolya BÁRTFAI-SZABÓ}

The regional tradition for developing linear rural homes has been reinvented for this family home. Referencing past works of respected

Hungarian architects and the influence of studying under the Mesteriskola and
Vándoriskola programs guided this project's architect. The home is divided into clear functional elements, daytime, nighttime with transitional areas that are linked by a common veranda. This in theory follows the Hungarian rural tradition: to a point, after which the architectural language and use of materials follow a more contemporary vein.

\section{WARE-NAGY, Orsolya: COMMUNITY BUILDING}

Citation: Metszet, Vol 11, No 4 (2020), pp 18-23, DOI: 10.33268/Met.2020.4.2

\section{SAINT PETER'S CATHEDRAL, WORMS, GERMANY | Artworks by: Anna HERINGER and Martin RAUCH}

In this project to redesign of liturgical spaces in a cathedral the community came together with artists to create rammed earth furnishings: the pulpit, altar and prayer stands amongst others. Instead of cement, here clay was put to the task to strengthen the rammed earth structures, meaning all materials were taken directly from nature. The link between nature and human activity being implemented at this level also helps to inform everyone that the so-called sophistication of western ideals does not really differ from out poorer counterparts elsewhere. Creativity is a proof of the brotherhood of man.

\section{GUTAI, Mátyás: TRADITION BALANCE}

Citation: Metszet, Vol 11, No 4 (2020), pp 24-29, DOI: 10.33268/Met.2020.4.3

\section{ODUNPAZARI MODERN MUSEUM, TURKEY | Architects: KENGO KUMA}

Kengo Kuma's museums always reinterpret local tradition, and his new work in Turkey, Odunpazari Modern Museum is another example of this design approach. Wooden architecture has great trradition in Turkey, so Kengo Kuma chose this material, which results in a playful appearance with horizontal wooden lamels and light filtering through. Not only the facades, but the floor plan was also influenced by vernacular architecture, hence the rotated building masses that also create new, contemporary public spaces.

GIUSTRA, Martina: AZULEJO, REVITALIZATION, RENZO PIANO

Citation: Metszet, Vol 11, No 4 (2020), pp 30-33, DOI: 10.33268/Met.2020.4.4

PRATA HOUSING COMPLEX, LISBON, PORTUGAL | Architects: RPBW, RENZO PIANO

Originally conceived just over twenty years ago the Prata Housing complex in Lisbon has finally moved ahead. Designed to be an energy aware redevelopment on a brown field, site where technical development of these residential units addresses issues of public and private spaces, orientation and azulejo a nod towards the regional use of azulaj tiles. The obvious similarity between locally produced ceramic tiles and the not intended decorative repetition of solar cells lead towards the development of a high tech azulej solar roof system, which generates energy, opens for means of ventilation and serves as a blue on white decorative motif.

\section{WETTSTEIN, Domonkos: STRUCTURAL DYNAMICS: ŐRMEZŐ CITY GATE}

Citation: Metszet, Vol 11, No 4 (2020), pp 34-39, DOI: 10.33268/Met.2020.4.5

BUDAPEST ONE OFFICE BUILDING, BUDAPEST, HUNGARY | Architects: Gergely PAULINYI, András REITH and István VÁMOSSY

Rust Belt redevelopment has led to the increase of flagship commercial building projects at key points along main arterial roads and railways into major cities. guided the design team towards an innovative use of generative design analysis which treats the building as a design object arrived at by the application of computable algorithms. The where controlled assessment of daylighting, ventilation and user patterns assisted in creating a free-flowing outer shell.

\section{BIHARI, Ádám - MEDGYASSZAY, Péter: PRESENT ADOBE CONSTRUCTION AND EXPECTED FUTURE TENDENCIES}

Citation: Metszet, Vol 11, No 4 (2020), pp 40-43, DOI: 10.33268/Met.2020.4.6

The construction industry faces many challenges over the next decade. Adobe or to be more accurate earth-based construction methods are limited when applied to traditional brick and wall finishes, yet with the advance of technology prefabricated or robotic solutions offer a viable way forward. Both traditional and future technologies will need to be regulated and monitored correctly considering financial, social and environmental impact. Once this is achieved embarking upon a path forwards can easily occur.

RUINUUK, I amas - UURASL RajnaIKa: HUIVGARIAIVINESI

Citation: Metszet, Vol 11, No 4 (2020), pp 44-47, DOI: 10.33268/Met.2020.4.7

NEW TYPES OF ENERGY SPACES IN SUSTAINABLE ARCHITECTURE

Developing ideas explored in the Solar Decathlon competition the reality of exploring how to improve on the Hungarian cube-like house type with the hope of expanding upon the use of vernacular elements to create a low-cost passive housing typology. Here the external and intermediate spaces have been included in the generation of a successful microclimatic experiment. Zoning of a home from private to public has proven to hold environmental impact solutions for energy positive homes.

MATOLCSY, Károly - TERJÉK, Anita - ZAJÁROS, Anett: REMOURBAN: SMART CITIES AND COMMUNITIES

Citation: Metszet, Vol 11, No 4 (2020), pp 48-51, DOI: 10.33268/Met.2020.4.8 METHODS, RESULTS, GOOD PRACTICE AND LESSONS

The EU project, Regeneration Model for accelerating the smart URBAN transformation, consists of 22 partnerships across 7 member states. Three existing city projects: Nottingham, Tepebaşi and Valladolid have returned positive results, now the project will be further expanded to the cities of Seraing and Miskolc. To date projects have focused upon smart infrastructure from the point of view of energy consumption, in Miskolc this will be extent towards public utilities and urban public transport. 